\title{
Mild energy restriction alters mouse-nematode transmission dynamics in free-running indoor arenas
}

\author{
M.E. Scott, O.K. Dare, T. Tu, and K.G. Koski
}

\begin{abstract}
Energy restriction reduces Heligmosomoides polygyrus (Dujardin, 1845) (Nematoda) infection by reducing transmission-related behaviours but prolongs parasite survival by suppressing immune responses in individually housed mice. To determine the relative importance of these two processes in accumulation of worms in mouse populations, 10 female CD1 mice were housed in each of eight indoor arenas with ad libitum access to either an energy-sufficient (ES) diet or an energy-restricted (ER) diet with $20 \%$ less metabolizable energy (four arenas per diet). After 3 weeks, $H$. polygyrus transmission was initiated by introducing larvae onto damp peat trays. Mice adapted to the ER diet through increased food intake and nesting and reduced overall activity; after 6 weeks, nutritional and immunological measures were comparable between diet groups. With continuing exposure to parasite larvae, mice in both ER and ES arenas developed resistance to the incoming larvae; however, mice in the ER arenas accumulated lower worm burdens than mice in the ES arenas despite their increased contact with peat. We suggest that the comparable immunocompetence of mice in the ER and ES arenas enabled the ER mice exposed to higher transmission rates to more rapidly reject the parasites, leading to lower final worm numbers, a pattern frequently observed in other helminth infections.
\end{abstract}

Résumé : Une carence énergétique diminue l'infection par Heligmosomoides polygyrus (Dujardin, 1845) (Nematoda) en réduisant les comportements associés à la transmission, mais prolonge la survie du parasite en supprimant la réponse immunitaire chez les souris logées individuellement. Afin de déterminer l'importance relative de ces deux processus sur l'accumulation de vers dans des populations de souris, nous avons logé 10 souris femelles CD1 dans chacune de huit arènes intérieures (quatre arènes par régime alimentaire) avec un accès ad libitum soit à un régime avec énergie suffisante (ES), soit à un régime réduit avec $20 \%$ de moins d'énergie métabolisable (ER). Au bout de 3 semaines, nous avons initié la transmission d'H. polygyrus en introduisant des larves sur des plateaux de tourbe humide. Les souris se sont adaptées au régime ER en augmentant leur ingestion de nourriture, restant au nid et réduisant leur activité générale; après 6 semaines, les variables nutritionnelles et immunologiques étaient semblables dans les deux groupes expérimentaux. Durant leur exposition prolongée aux vers, les souris des arènes ER et ES ont développé une résistance à l'ingestion continue de larves, mais les souris des arènes ER ont accumulé des charges parasitaires plus faibles que celles des souris dans les arènes ES, malgré leur contact plus grand avec la tourbe. Nous croyons que l'immunocompétence similaire chez les souris des arènes ER et ES a permis aux souris ER exposées à des taux de transmission plus élevées de rejeter plus rapidement les parasites, ce qui explique la charge parasitaire finale plus faible, un phénomène souvent observé dans d'autres infections à helminthes.

[Traduit par la Rédaction]

\section{Introduction}

In natural environments, mice and other small rodents are particularly vulnerable to fluctuations in availability and quality of food because of the high cost of thermoregulation and the limited adipose tissue available for energy storage owing to their small body size (Perrigo and Bronson 1985; Bronson et al. 1991). As a consequence, they may optimize use of limited energetic resources by altering their behaviour or prioritizing certain metabolic functions over others (Sheldon and Verhulst 1996; Derting and Compton 2003; Sandland and Minchella 2003). For example, during periods of high metabolic demand or energy restriction, nocturnal wood mice (Apodemus sylvaticus (L., 1758)) seek food during daylight despite the increased risk of predation (Corp et al. 1997), and laboratory rodents reduce oxygen consump-

Received 2 September 2004. Accepted 31 March 2005. Published on the NRC Research Press Web site at http://cjz.nrc.ca on 16 June 2005.

M.E. Scott ${ }^{1}$ and O.K. Dare. ${ }^{2}$ Institute of Parasitology, McGill University (Macdonald Campus), 21, 111 Lakeshore Road, SainteAnne-de-Bellevue, QC H9X 3V9, Canada.

T. Tu and K.G. Koski. School of Dietetics and Human Nutrition, McGill University (Macdonald Campus), 21, 111 Lakeshore Road, Sainte-Anne-de-Bellevue, QC H9X 3V9, Canada.

${ }^{1}$ Corresponding author (e-mail: marilyn.scott@mcgill.ca).

${ }^{2}$ Present address: Department of Biology, Carleton University, 1125 Colonel By Drive, Ottawa, ON K1S 5B6, Canada. 
tion and resting metabolic rate (McCarter and McGee 1989; Kristan and Hammond 2001; Santos-Pinto et al. 2001). Infectious disease is another stress that may induce similar behavioural or metabolic changes. Metabolic requirements are increased by infectious diseases both because of the need for increased tissue repair and because of up-regulation of the immune system (Demas et al. 1997; Colditz 2002).

Previous research in our laboratory has demonstrated that energy restriction has opposite effects on numbers of the gastrointestinal nematode Heligmosomoides polygyrus (Dujardin, 1845) depending on whether mice are infected by oral gavage with infective larvae or by a more natural transmission process dependent on behaviours that bring the mice in contact with larvae in the environment. When energyrestricted mice are fed parasite larvae by oral gavage, parasite survival is prolonged and immune responses are reduced (Shi et al. 1997; Koski et al. 1999), indicating that energy restriction prevents mice from mounting appropriate protective responses and thus leads to elevated worm burdens. In contrast, in the case of behaviour-dependent transmission, energy restriction reduces the uptake of free-living parasite larvae, perhaps because of decreased grooming by energyrestricted mice (Heitman et al. 2003). Thus, our tightly controlled laboratory studies indicate that energy restriction reduces transmission but prolongs parasite survival. Although infection and energy restriction are likely to occur together, there is little information about the interplay between these two stresses except under such tightly controlled conditions.

The objectives of this study were to explore nutritional, behavioural, parasitological, and immunological responses of mouse populations given ad libitum access to either energysufficient or energy-restricted diets in the presence of continuous exposure to $H$. polygyrus larvae in indoor enclosures. Natural infection occurs when mice ingest larvae from the soil or when larvae that move onto the fur are accidentally ingested during either self-grooming or allo-grooming (Tanguay and Scott 1992; Hernandez and Sukhdeo 1995). On first exposure, ingested parasite larvae migrate into the serosal musculature, where they grow and develop for approximately 7 days before migrating into the lumen of the duodenum, maturing and releasing eggs in the faeces. Under moist conditions, eggs hatch and undergo two molts to thirdstage infective larvae within about 7 days. A first infection lasts for several months, but repeated exposure to larvae normally elicits a protective host response that causes worm numbers to increase then gradually decline despite continuing exposure to infective larvae (Kerboeuf 1982; Slater and Keymer 1986; Scott 1991).

In our experiment, food intake, mass gain, and mouse behaviours (feeding, grooming, contact with peat, nesting, total activity) were monitored beginning 3 weeks prior to introduction of the parasite into the enclosures; over the following 9 weeks, parasite transmission dynamics and circulating IgE levels were also monitored. Extrapolating from our previous experiments on individually housed mice to the more natural situation of behaviour-dependent transmission in small mouse populations, we predicted that dietary restriction of energy would generate energy-deficient mice with reduced mass gain, and that these mice would groom less and would have decreased contact with parasite larvae on the peat substrate (presumably leading to decreased parasite transmission) but would have reduced circulating IgE levels, indicating immunosuppression that would permit prolonged parasite survival and thus lead to elevated infection levels.

\section{Materials and methods}

\section{Experimental design and protocol}

Our 12-week biphasic experiment included a 3-week preinfection phase (phase I, day -21 through day -1) and a 9week postinfection (p.i.) phase (phase II, days 0 through 64 p.i.) with two dietary treatments: energy-sufficient (ES) and energy-restricted (ER). To facilitate interpretation of interactions with parasite dynamics, phase II was separated into early (days 0 through 21 p.i.) and late (days 22 through 64 p.i.) postinfection phases (phases IIa and IIb, respectively), based on previous observations that parasites accumulate during the first 3 weeks following trickle infection and then decline (Scott 1991). Ten female mice were randomly assigned to each of eight indoor arenas (four arenas per diet group). Food consumption, body mass, mouse behaviours, larval availability in the arenas, and parasite egg production were recorded throughout the study. One pair of arenas (one ER arena and one ES arena) was terminated at each of 11, 20, 43, and 64 days p.i., at which time mice were anesthetized with a ketamine:acepromazine $(1: 2.6)$ cocktail $(0.004 \mathrm{~mL} \cdot(\mathrm{g}$ body mass $)^{-1}$ ) injected intramuscularly. They were exsanguinated for later measurements of antibody titers and $\beta$ hydroxybutyrate (BHA) concentrations, and the intestines were removed and the numbers of worms recorded. For logistic reasons, the starting times for the four pairs of ER and ES arenas were staggered over 10 weeks.

\section{Arenas, mice, and parasites}

Four Plexiglas ${ }^{\circledR}$ boxes $(41 \mathrm{~cm} \times 81 \mathrm{~cm} \times 30.5 \mathrm{~cm})$ were constructed with perforated exterior walls to allow airflow but solid lids to ensure clarity of recordings by a ceilingmounted camera. Each box was divided into two arenas by a solid Plexiglas wall that prevented chemical communication between mice in the two arenas. The mice demonstrated no interest in those in the adjacent arena. Water bottles and feeders (Lab Products Inc., Montréal, Quebec) especially designed to minimize spillage of powdered diets were positioned on opposite sides within each arena. The floor was covered with a layer of pine shavings, and refuge tubes were used to reduce aggression and provide environmental enrichment. Ten 4-week-old, female, outbred CD-1 mice (Charles River Canada, Saint-Constant, Quebec) were introduced into each of the eight arenas at the beginning of the experiment and were maintained in a long daylight cycle (14 h light : $10 \mathrm{~h}$ dark) consistent with summer months. Each mouse was individually marked with permanent, nontoxic yellow picric acid, visible during daylight hours, and non-permanent, nontoxic black tempera paint, detectable under infrared light. Arenas were cleaned every 2 weeks and mice were monitored daily for signs of injury or illness. All procedures were conducted according to the Canadian Council on Animal Care (1984) and were approved by the McGill Animal Care Committee.

Two stainless steel trays $(30 \mathrm{~cm} \times 25 \mathrm{~cm} \times 4 \mathrm{~cm})$ filled with sterilized damp peat moss and covered with stainless steel mesh $(6 \mathrm{~mm} \times 6 \mathrm{~mm})$ were placed at opposite ends of 
each arena at least 2 inches away from the walls. At the beginning of phase II, 4000 infective third-stage larvae $\left(\mathrm{L}_{3}\right)$ of $H$. polygyrus were pipetted onto the surface of each of the trays to initiate parasite transmission. Subsequently, parasite eggs were continuously deposited onto the trays when mice defecated. Infection occurred either by direct ingestion of larvae from the peat or by accidental ingestion of larvae on the fur during grooming. The surface of the peat was sprayed regularly with water to maintain moisture sufficient for survival of parasite larvae. Each peat tray was removed and cleaned every 2 weeks, in an alternating cycle, to retain a continuous source of infection in each arena.

\section{Diets}

Semi-purified, biotin-fortified, egg-white-based powder diets were formulated as either energy-sufficient (ES) or energyrestricted (ER; $80 \%$ of metabolizable energy of ES diet) (Table 1). Vitamins and minerals were included at levels sufficiently greater than required by the mouse (National Research Council 1995) to prevent deficiencies in case some mice had reduced food intake. To offset the biotin-chelating effects of avidin in the egg white solids, biotin was increased to 18 times the level recommended by the National Research Council (1995).

\section{Nutritional status indicators}

Total food consumption in each arena was measured daily. The mass of each mouse was recorded at the beginning of the experiment, on days $-14,-11,-7$, and -2 of phase I, and weekly from the beginning of phase II. During fasting or mass loss, when fat is burned as a source of energy, BHA and other ketone bodies are produced (Miller et al. 1982; Hunter and Sadler 1987). In our experiment, the concentration of BHA was measured from terminal serum samples (Kit 310-A UV, Sigma Diagnostics, St. Louis, Missouri).

\section{Infection indicators}

Larval availability on peat trays was determined immediately before trays were cleaned. The peat tray was placed in a cage $(30 \mathrm{~cm} \times 34 \mathrm{~cm} \times 17 \mathrm{~cm})$, then eight or nine uninfected female CD1 "sentinel" mice, age-matched to experimental mice, were placed in the cage for $24 \mathrm{~h}$. The peat tray was then immediately cleaned, filled with sterilized peat, and returned to the arena. The sentinel mice were moved into conventional cages with no further larval exposure. One week later they were killed with $\mathrm{CO}_{2}$, their small intestines were removed, and parasite burdens were quantified (Scott 1990).

Beginning on day 20 of phase II, parasite egg production was monitored weekly. Mice were removed from arenas for $24 \mathrm{~h}$ and placed on wire grids suspended above approximately $100 \mathrm{~mL}$ of water in Nalgene cages $(26 \mathrm{~cm} \times 20 \mathrm{~cm})$. Net egg production per day (epd) was estimated using the modified McMaster technique (Scott 1988). At necropsy, the number of parasites in the intestine was also recorded (Scott 1988).

\section{Circulating IgE}

Total serum IgE was measured by two-site ELISA following the manufacturer's directions (BD PharMingen, Mississauga, Ontario). Immulon ${ }^{\mathrm{TM}} 2$ plates (Thermo Electron Corp.) were coated with rat anti-mouse IgE monoclonal antibody (R35-72, BD PharMingen) and developed with biotinylated
Table 1. Composition of experimental diets $\left(\mathrm{g} \cdot(\mathrm{kg} \mathrm{diet})^{-1}\right)$ : ES, energy-sufficient; ER, energy-restricted (80\% of energy of ES diet).

\begin{tabular}{|c|c|c|}
\hline Ingredients $^{a}$ & ES diet & ER diet \\
\hline Ovalbumin (type P-110) & 245 & 200 \\
\hline Corn oil & 75 & 60 \\
\hline Cornstarch & 290 & 232 \\
\hline Glucose (anhydrous dextrose) & 290 & 232 \\
\hline Cellulose (hydrolyzed Alpha-Cel ${ }^{\mathrm{TM}}$ ) & 42 & 218 \\
\hline Vitamin $\operatorname{mix}^{b}$ & 12 & 12 \\
\hline Mineral $\operatorname{mix}^{c}$ & 46 & 46 \\
\hline
\end{tabular}

${ }^{a}$ ICN Biochemicals Canada Ltd., Montréal, Quebec.

${ }^{b}$ Vitamin mix (per kg of diet): retinyl acetate (vitamin A), $8 \mathrm{mg}$ (4000 IU); cholecalciferol (vitamin D), $0.025 \mathrm{mg}$ (1000 IU); alphatocopherol acetate (vitamin E), $60 \mathrm{mg}$ (60 IU); phylloquinone (vitamin $\mathrm{K}$ ), $9 \mathrm{mg}$; biotin, $3.6 \mathrm{mg}$; choline bitartrate, $3996 \mathrm{mg}$; folic acid, $2.04 \mathrm{mg}$; niacin, $50.04 \mathrm{mg}$; D-calcium pantothenate, $31.2 \mathrm{mg}$; riboflavin, $24 \mathrm{mg}$; thiamin, $15.96 \mathrm{mg}$; pyridoxine $\mathrm{HCl}$ (vitamin B-6), $3.96 \mathrm{mg}$; cyanocobalamin (vitamin B-12), $50.04 \mathrm{mg}$; butylated hydroxytoluene, $99.6 \mathrm{mg}$. Note that because of an error in preparation of the vitamin mix, the cyanocobalamin concentration was 5000-fold higher than intended in both the ES and the ER diets.

${ }^{c}$ Mineral mix (per kg of diet): $\mathrm{CaHPO}_{4}, 27.16 \mathrm{~g} ; \mathrm{KHCO}_{3}, 10.25 \mathrm{~g}$; $\mathrm{NaCl}, 2.54 \mathrm{~g} ; \mathrm{MgSO}_{4}, 4.95 \mathrm{~g} ; \mathrm{CrK}\left(\mathrm{SO}_{4}\right)_{2} \cdot 12 \mathrm{H}_{2} \mathrm{O}, 0.0384 \mathrm{~g} ; \mathrm{CuCO}_{3} \cdot \mathrm{Cu}(\mathrm{OH})_{2}$, $0.01563 \mathrm{~g} ; \mathrm{KIO}_{3}, 0.001 \mathrm{~g} ; \mathrm{FeSO}_{4} \cdot 7 \mathrm{H}_{2} \mathrm{O}, 0.2489 \mathrm{~g} ; \mathrm{MnCO}_{3}, 0.1883 \mathrm{~g}$; $\mathrm{ZnCO}_{3}, 0.115 \mathrm{~g} ; \mathrm{Na}_{2} \mathrm{SeO}_{3}, 0.0004 \mathrm{~g} ; \mathrm{Na}_{2} \mathrm{MoO}_{4} \cdot 2 \mathrm{H}_{2} \mathrm{O}, 0.0002519 \mathrm{~g}$; $\mathrm{KF} \cdot 2 \mathrm{H}_{2} \mathrm{O}, 0.0099 \mathrm{~g}$; citric acid, $0.4822 \mathrm{~g}$ (from Anachemia, except $\mathrm{ZnCO}_{3}$ from Fisher Scientific, Montréal, Quebec).

rat anti-IgE monoclonal antibody (R35-92, BD PharMingen) and avidin-peroxidase (BD PharMingen). 3,3',5,5'-tetramethylbenzidine was used as a substrate. After the reaction was stopped with phosphoric acid, the plates were read with an EL309 Microplate Autoreader (Bio-Tek Instruments, Inc., Winooski, Vermont) at $450 \mathrm{~nm}$. IgE concentration $(\mu \mathrm{g} \cdot(\mathrm{mL}$ serum $)^{-1}$ ) was determined from an $\operatorname{IgE}$ standard curve with known concentrations of mouse IgE standard (C38-2, BD PharMingen).

\section{Behaviours}

At the beginning of the experiment, 4 of the 10 mice in each arena were randomly selected for repeated observations throughout the study. Mouse behaviours were recorded on days -5 and -1 (phase I), days 10 and 19 p.i. (phase IIa), and days 41 and 62 p.i. (phase IIb). Concurrent surveillance of each pair of arenas (ER and ES) was conducted with the aid of a ceiling-mounted infrared-receptive camera (Electrophysics Corp., Fairfield, New Jersey) and a videocassette recorder, in the absence of the investigator. Four 30-min recording sessions were initiated at the same times on each observation day: 5 and $9 \mathrm{~h}$ into the light photoperiod and 3 and $7 \mathrm{~h}$ into the dark photoperiod. The duration of each behaviour was recorded with a stopwatch with split memory capacity, in sequence, while replaying the videotape. The behavioural repertoire was recorded according to van Oortmerssen (1971), Mackintosh (1981), and personal observations (Table 2). Of particular interest were feeding, grooming (involved in parasite transmission), and nesting (expected to increase in mice from ER arenas as a means of reducing energy expenditure). In addition, two composite behaviour measures were compiled over the two light or two dark observation periods per day (total duration of $60 \mathrm{~min}$ for each). 
Table 2. Definition of behaviours recorded, adapted from van Oortmerssen (1971) and Mackintosh (1981).

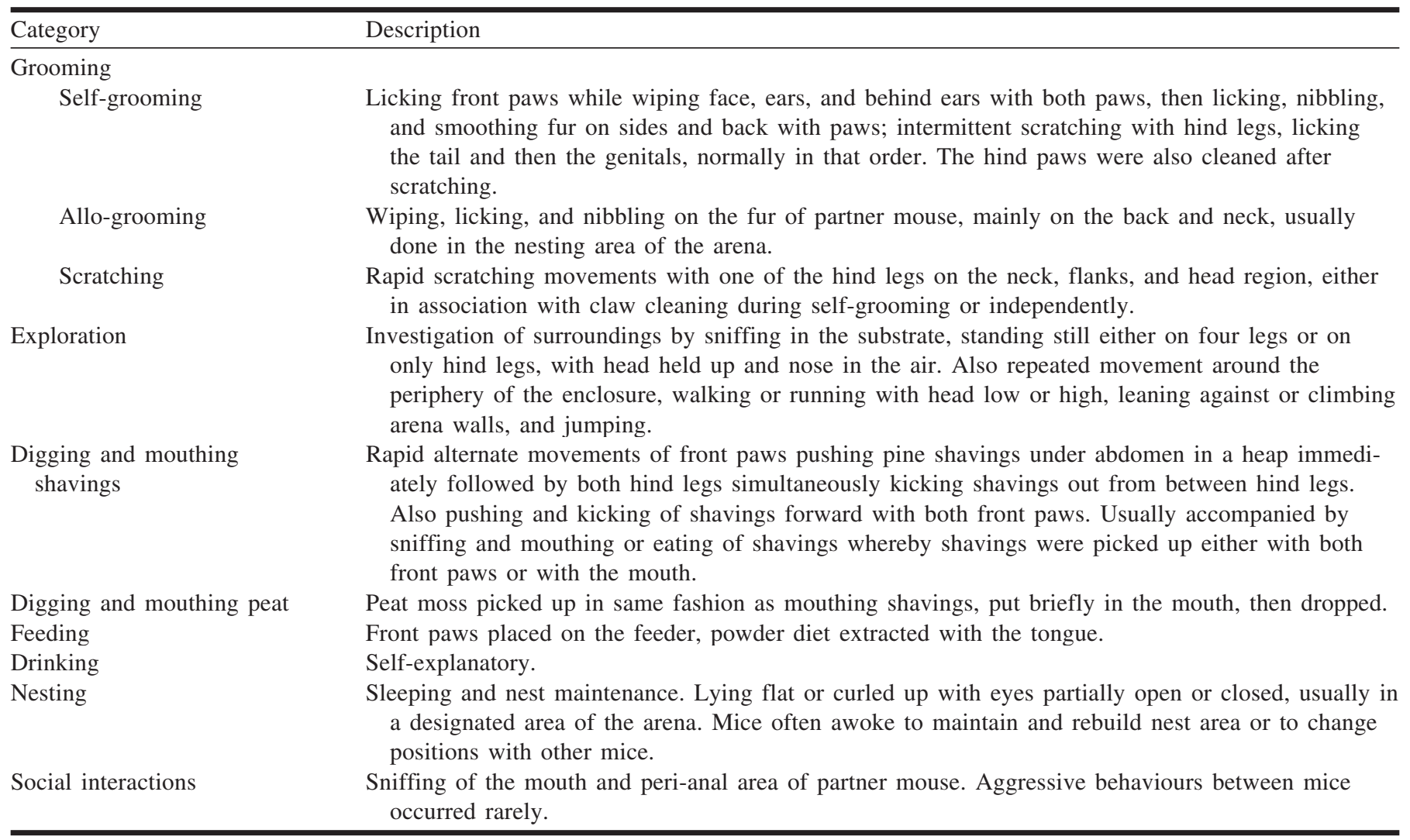

(1) Cumulative contact with peat: the sum of all behaviours that occurred while mice were on the peat trays. Transmission requires contact with the peat trays both to deposit parasite eggs and to pick up larvae, which move onto the fur of the mouse or are ingested directly.

(2) Total activity: the number of times the mouse changed from one behaviour to another, used as an indication of hyper (or hypo) activity induced either by diet or by infection.

\section{Data analyses}

Two-way ANOVA with Tukey's post-hoc multiple comparison was used to analyze the main effects of diet, time, and their interactions on all terminal outcomes from each pair of ER and ES arenas (BHA concentrations, worm burdens, and antibody titers) and on average daily food consumption per arena per week. Repeated-measures ANOVA with a spatial power covariance structure and a KenwardRoger adjustment of degrees of freedom was used to investigate the effects of diet and time on the pattern of body mass, natural $\log$ of net egg production, and total activity, with mice nested by arena. Where appropriate, this was followed by diet comparisons by ANOVA at individual time points.

To overcome pseudo-replication introduced by repeated behaviour measurements on the same mice, behavioural data for each mouse were summed for the two 30-min observation periods per day in each photoperiod (light and dark), then averaged across the two observation days for each phase of the experiment (phases I, IIa, and IIb) to give duration per
$60 \mathrm{~min}$, number of bouts per $60 \mathrm{~min}$, and average bout length for light and dark photoperiods. Total activity was compared between dark and light photoperiods using a paired $t$ test. All analyses of other individual behaviours were done using nonparametric statistics (Kruskal-Wallis one-way ANOVA) to overcome the non-normal distribution of data. Significance was established at the $P \leq 0.05$ level except for the behaviour data, where $P$ values between 0.05 and 0.1 were considered biologically meaningful and are reported.

\section{Results}

\section{Nutritional status}

Average daily food intake per arena per week varied over time $\left(F_{[11,40]}=17.65, P<0.0001\right)$ and was approximately $10 \%$ higher in the ER arenas $\left(31.75 \pm 0.41 \mathrm{~g} \cdot\right.$ arena $^{-1} \cdot$ day $\left.^{-1}\right)$ than in the ES arenas $\left(29.02 \pm 0.32 \mathrm{~g} \cdot \mathrm{arena}^{-1} \cdot \mathrm{day}^{-1}\right)$ $\left(F_{[1,40]}=24.54, P<0.0001\right.$; Fig. $\left.1 a\right)$. Thus, despite the $20 \%$ reduction in energy density of the ER diet, energy intake of ER mice was only $10 \%$ lower because of increased food intake. The reduced energy intake resulted in mice in the ER arenas having lower masses than mice in the ES arenas (Fig. $1 b$ ) during phase I (day $-14, F_{[1,72]}=5.76, P=0.019$; day $\left.0, F_{[1,54]}=4.11, P=0.0476^{3}\right)$. Within phase IIa, the relative masses of mice in the ER and ES arenas shifted. During the first week p.i., masses continued to be significantly lower in mice in the ER arenas (day $7, F_{[1,72]}=7.72, P=$ $0.007)$, whereas by day 14 p.i., mass differences were reduced $\left(F_{[1,54]}=3.86, P=0.0545\right)$, and all subsequent com-

\footnotetext{
${ }^{3}$ Body mass data on day 0 were available for only six of the eight arenas.
} 
Fig. 1. Changes over time in $(a)$ average food intake per arena per week and $(b)$ body mass between CD1 mice fed either an energysufficient (ES) or an energy-restricted (ER) diet. The ER diet contained $80 \%$ of the metabolizable energy of the ES diet; thus, for every gram of food ingested, mice fed the ER diet consumed $80 \%$ of the energy ingested by mice fed the ES diet. Data shown are means \pm SE of all individuals in all arenas. An asterisk indicates a significant difference $(P<0.05)$ between diet groups; a plus sign indicates borderline significance $(P=0.0545)$ between ER and ES arenas; and different capital letters indicate a significant difference in masses of mice in ES arenas between days 14 and 28 after exposure to larvae of Heligmosomoides polygyrus.
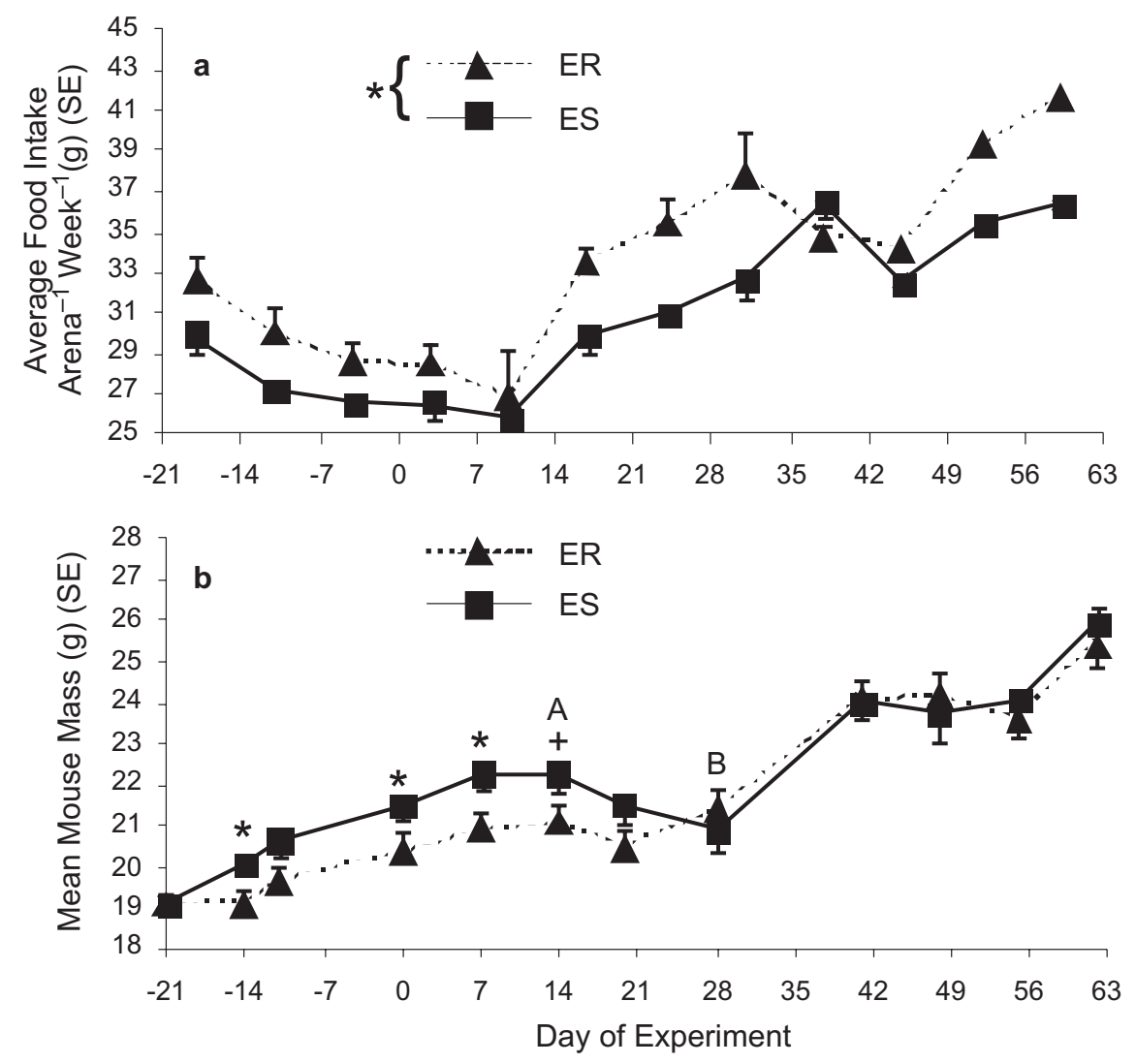

parisons revealed no significant differences in body masses between mice in the ER and the ES arenas. The ability of mice in the ER arenas to achieve body masses comparable to those of mice in the ES arenas was also facilitated by infection-induced mass loss in mice in the ES arenas and by conservation of energy through increased nesting in mice in the ER arenas. Between days 14 and 28 p.i., mice in the ES arenas lost mass (paired $t$ test, $t_{[19]}=3.148, P=0.0053$ ), whereas the mass of mice in the ER arenas was stable (paired $t$ test, $\left.t_{[18]}=-0.104, P=0.9180\right)$. No differences were detected in BHA concentrations between diet groups, but BHA concentrations were higher on day 43 p.i. (422 \pm $\left.80 \mu \mathrm{mol} \cdot \mathrm{L}^{-1}\right)$ than at the other times $\left(132 \pm 13 \mu \mathrm{mol} \cdot \mathrm{L}^{-1}\right)$ $\left(F_{[3,68]}=13.34, P<0.0001\right)$.

\section{Circulating IgE}

IgE titers did not differ between ER and ES arenas. This is consistent with the nutritional status indicators showing that mice fed the ER diet were metabolically similar to those fed the ES diet during most of phases IIa and IIb, despite the $10 \%$ reduction in net caloric intake. However, $\operatorname{IgE}$ was higher on day 43 p.i. $\left(106 \pm 14 \mu \mathrm{g} \cdot \mathrm{mL}^{-1}\right)$ than on the other days $\left(64 \pm 5 \mu \mathrm{g} \cdot \mathrm{mL}^{-1}\right)\left(F_{[3,63]}=6.57, P=0.0006\right)$, indicating a heightened systemic immune response at this time. This is consistent with the increased BHA concentrations observed at the same time, highlighting the increased metabolic demand associated with immune responsiveness.

\section{Parasite transmission dynamics}

In contrast to the traditional controlled gavage infection of individual mice, our protocol enabled mice to freely and continuously contact parasite larvae that we had placed on the damp peat and to subsequently come in contact with larvae that had developed from eggs deposited onto the peat in the faeces of infected mice. The presence of parasites in sentinel mice exposed for $24 \mathrm{~h}$ to the peat trays (Fig. $2 a$ ) provided evidence of continual availability of parasite larvae in the arenas. Parasite numbers in sentinel mice varied significantly over time $\left(F_{[5,167]}=140.84, P<0.0001\right)$, and a significant diet $\times$ time interaction was detected $\left(F_{[5,167]}=25.91, P<0.0001\right)$. Soon after transmission began (phase IIa), larval uptake by sentinel mice was similar in ER and ES arenas (days 7 and 14 p.i.). However, dietary differences emerged during phase IIb. By day 36 p.i., our data from sentinel mice indicated that mice in the ER arenas were exposed to higher numbers of larvae than those in the ES arenas $\left(F_{[1,14]}=24.57, P=0.0002\right)$, whereas on days 41 and 55 p.i., sentinel mice exposed to peat trays from the ES arenas had more larvae than mice exposed to peat trays from the ER arenas $\left(F_{[1,15]}=14.83, P=0.0016\right.$; $F_{[1,16]}=9.06, P=0.0083$, respectively). 
Fig. 2. Changes over time in (a) number of $H$. polygyrus acquired by sentinel mice exposed to peat trays from arenas with energysufficient (ES) or energy-restricted (ER) diets and $(b)$ worm burden in experimental CD1 mice fed either the ES or the ER diet. Data shown are means \pm SE. An asterisk indicates a significant difference $(P<0.05)$ between ER and ES arenas either overall $(b)$ or at the specific time point indicated $(a)$; different capital letters indicate significant differences among time points.

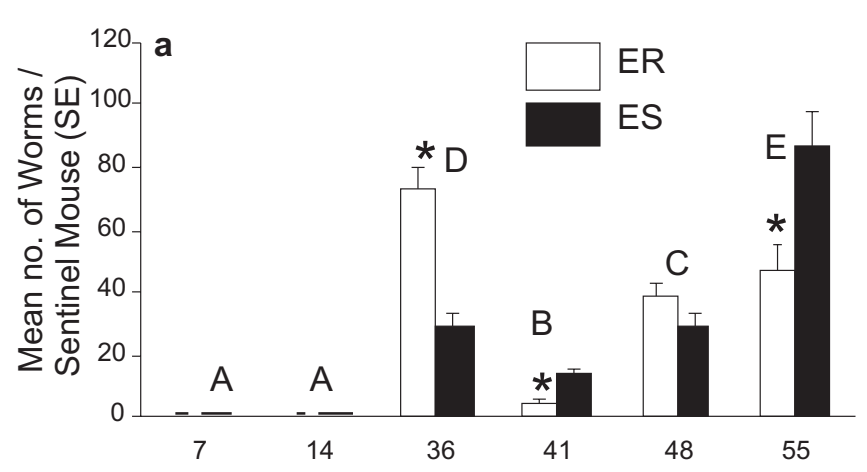

Day of Experiment

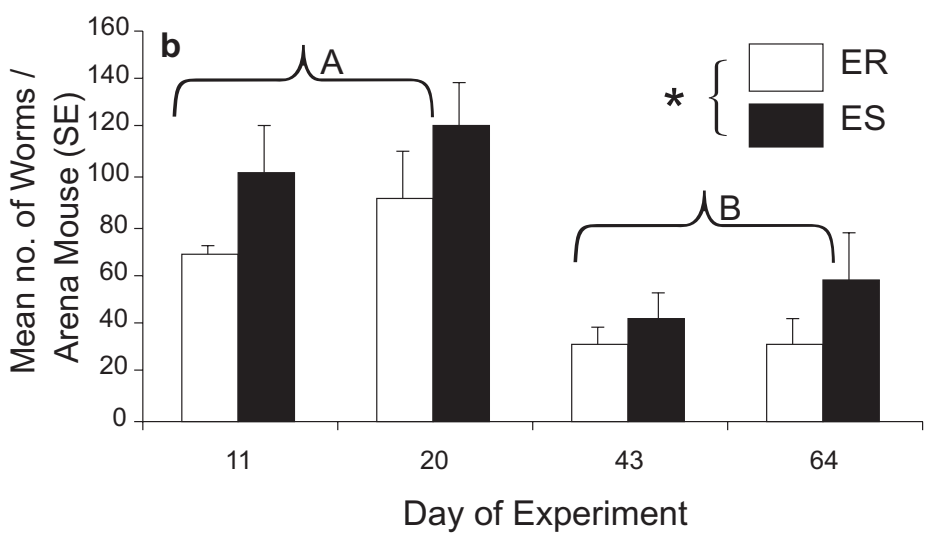

Table 3. Effect of photoperiod on behaviour of CD1 mice.

\begin{tabular}{|c|c|c|c|c|}
\hline Behaviour & Parameter & Dark photoperiod & Light photoperiod & Statistics \\
\hline Total activity & No. of bouts per $60 \mathrm{~min}$ & $147.6 \pm 4.8(140)$ & $23.6 \pm 2.4(16)$ & $t_{[119]}=21.5, P<0.0001$ \\
\hline \multirow[t]{3}{*}{ Contact with peat } & Duration (s) & $515 \pm 28(483.6)$ & $17 \pm 4(0.6)$ & $\chi^{2}=108.7, P<0.0001$ \\
\hline & No. of bouts per $60 \mathrm{~min}$ & $59.7 \pm 2.7(59.7)$ & $2.8 \pm 0.5(0.25)$ & $\chi^{2}=109.9, P<0.0001$ \\
\hline & Bout length (s) & $8.6 \pm 0.4(8.0)$ & $5.2 \pm 1.0(3.6)$ & $\chi^{2}=37.4, P<0.0001$ \\
\hline \multirow[t]{3}{*}{ Feeding } & Duration (s) & $654 \pm 46(580)$ & $43 \pm 15(0)$ & $\chi^{2}=105.5, P<0.0001$ \\
\hline & No. of bouts per $60 \mathrm{~min}$ & $6.2 \pm 0.4(6.0)$ & $0.6 \pm 0.1(0)$ & $\chi^{2}=101.4, P<0.0001$ \\
\hline & Bout length (s) & $115 \pm 8(96)$ & $80 \pm 13(56)$ & $\chi^{2}=10.1, P<0.0015$ \\
\hline \multirow[t]{3}{*}{ Grooming } & Duration (s) & $372 \pm 28(307)$ & $307 \pm 35(252)$ & $\chi^{2}=5.8, P=0.0156$ \\
\hline & No. of bouts per $60 \mathrm{~min}$ & $21.9 \pm 1.1(23.0)$ & $7.4 \pm 1.0(4.5)$ & $\chi^{2}=72.0, P<0.0001$ \\
\hline & Bout length (s) & $17 \pm 1(14)$ & $52 \pm 5(39)$ & $\chi^{2}=40.2, P<0.0001$ \\
\hline \multirow[t]{3}{*}{ Nesting } & Duration (s) & $1062 \pm 69(1024)$ & $3115 \pm 54(3256)$ & $\chi^{2}=105.3, P<0.0001$ \\
\hline & No. of bouts per $60 \mathrm{~min}$ & $7.1 \pm 0.3(7.25)$ & $6.6 \pm 0.5(5.0)$ & $\chi^{2}=4.4, P=0.0366$ \\
\hline & Bout length (s) & $187 \pm 20(145)$ & $763 \pm 60(585)$ & $\chi^{2}=73.5, P<0.0001$ \\
\hline
\end{tabular}

Note: Parameters were averaged per 60 min of observation per phase (mean \pm SE; median in parentheses) and analysed by paired $t$ test or KruskalWallis one-way ANOVA. Only parameters with a $P$ value $<0.1$ are reported.

Despite continuing availability of larvae in the arenas, worm numbers in mice living in both the ER and the ES arenas declined in phase IIb (days 43 and 64 p.i.) relative to phase IIa (days 11 and 20 p.i.) $\left(F_{[3,71]}=10.05, P<0.0001\right)$ (Fig. 2b) and net egg production declined after day 20 p.i. $\left(F_{[9,194]}=2.92, P=0.0029\right)$. Overall, worm numbers were higher in mice living in the ES arenas than in those living in the ER arenas $\left(F_{[1,71]}=5.88, P=0.0179\right)$ (Fig. $\left.2 b\right)$, but despite the borderline higher egg production in mice from the ES arenas (8515 \pm 1395 epd, median 7098) compared with mice from the ER arenas (5569 \pm 791 epd, median 4536) $\left(F_{[1,58]}=4.51, P=0.0714\right)$ during phase IIa, overall there was no significant effect of diet on net egg production $\left(F_{[1,67]}=0.76, P=0.3859\right)$.

\section{Interplay with behaviour}

As expected (Kowal et al. 2002), mice were significantly more active during dark than during light photoperiods (Table 3). The vast majority of feeding and contact with peat occurred during the dark photoperiod and resulted from feeding and peat contact bouts being both more frequent and longer. More time was also spent grooming during the dark photoperiod, in more frequent but shorter bouts. In contrast, mice slept significantly more during the light photoperiod, in less frequent but longer nesting bouts.

First, we considered whether mice from the ER arenas exhibited changes in behaviour consistent with increased food intake (increased feeding) or conservation of energy (increased nesting and (or) decreased total activity). During the dark photoperiods of phase I (Table 4), mice in the ER arenas spent more time feeding than mice in the ES arenas (Table 4), but they showed no difference in duration of nesting or total activity (data not shown) despite having significantly fewer nesting bouts (Table 4). After introduction of the parasite into the arenas (phase IIa), mice in the ER arenas had less frequent but longer feeding and nesting bouts than mice in the ES arenas (Table 4), but these differences did not result in differences in our estimates of total activity or total time spent feeding or nesting (data not shown).

Next, we considered whether infection altered mouse behaviours by comparing preinfection phase I with postinfection phases IIa and IIb (Table 5). Analysis of total activity per day revealed a significant interaction between diet and phase $\left(F_{[2,66]}=3.31, P=0.0425\right)$. Further exploration 
Table 4. Effect of diet (ER, energy-restricted; ES, energy-sufficient) on mouse behaviour.

\begin{tabular}{lllllll}
\hline Behaviour & Parameter & Phase & Photoperiod & ES diet & ER diet & Statistics \\
\hline Contact with peat & Bout length (s) & IIa & Dark & $8.0 \pm 0.7(7.0)$ & $10.4 \pm 1.0(9.6)$ & $\chi^{2}=4.0, P=0.0269$ \\
& Duration (s) & IIb & Dark & $392 \pm 64(400)$ & $671 \pm 131(603)$ & $\chi^{2}=3.8, P=0.05$ \\
& No. of bouts per 60 min & IIb & Dark & $51.2 \pm 5.7(45.5)$ & $76.2 \pm 9.9(74.5)$ & $\chi^{2}=3.4, P=0.0651$ \\
Feeding & Duration (s) & I & Dark & $500 \pm 48(473)$ & $771 \pm 89(690)$ & $\chi^{2}=6.4, P=0.0114$ \\
& No. of bouts per 60 min & IIa & Dark & $7.7 \pm 0.7(8.5)$ & $5.3 \pm 1.0(4.2)$ & $\chi^{2}=4.8, P=0.0282$ \\
& Bout length (s) & IIa & Dark & $103 \pm 16(94)$ & $166 \pm 28(125)$ & $\chi^{2}=3.3, P=0.0690$ \\
Nesting & No. of bouts per 60 min & I & Dark & $8.4 \pm 0.6(9.0)$ & $6.4 \pm 0.6(7.2)$ & $\chi^{2}=4.9, P=0.0275$ \\
& No. of bouts per 60 min & IIa & Light & $8.0 \pm 1.4(6.5)$ & $4.7 \pm 0.8(3.5)$ & $\chi^{2}=2.7, P=0.0996$ \\
& Bout length (s) & IIa & Light & $690 \pm 150(495)$ & $881 \pm 109(762)$ & $\chi^{2}=2.8, P=0.0932$ \\
\hline
\end{tabular}

Note: Parameters were averaged per 60 min of observation per phase (mean \pm SE; median in parentheses) and analysed by Kruskal-Wallis one-way ANOVA. Only parameters with $P$ values $<0.1$ are reported.

showed that activity was significantly depressed during phase IIa for mice in the ER arenas compared with phases I and IIb, whereas activity was depressed in phase IIb for mice in the ES arenas compared with phase I. During phase IIa, when worm numbers were highest, feeding duration (ER arenas, dark photoperiod) was elevated, whereas bouts of peat contact (ER arena, dark photoperiod) and grooming were less frequent (ER arena, light photoperiod) compared with the other phases (Table 5). During phase IIb, when exposure to larvae in all arenas was higher than in phase IIa but worm numbers in the mice were lower, both the frequency of grooming and the total time spent grooming were reduced (ES mice, light photoperiod) and nesting duration and bout length were elevated (ES mice, light photoperiod) compared with phases I and IIa (Table 5).

Finally, we evaluated the effect of reduced energy intake on behaviours previously shown to be involved in transmission of larvae (grooming and contact with peat trays). No significant differences were detected between mice in the ER and ES arenas for any of the grooming parameters or for the specific behaviour of digging and mouthing peat. However, the average length of bouts of contact with peat was higher in mice in the ER arenas during the dark photoperiod of phase IIa (Table 4), and the total duration and frequency of contact with peat (dark photoperiod) were also higher in mice from the ER arenas than in mice from the ES arenas in phase IIb (Table 4), indicating that mice in the ER arenas had more contact with larvae on the peat than mice in the ES arenas.

\section{Discussion}

We had previously demonstrated that individually housed mice did not adjust food intake to compensate for a reduction in energy content in the diet of up to $25 \%$ despite ad libitum access to the diet over 8 weeks (Koski et al. 1999). In the present study, however, mice housed as a population with ad libitum access to the ER diet consumed an average of $10 \%$ more food, as evidenced by both increased food consumption (Fig. 1a) and increased feeding behaviours (Table 4). Based on patterns of mass gain (Fig. 1b), the resulting decrease in energy intake was sufficient to cause impaired growth of ER mice relative to ES mice, but only through preinfection phase I and early postinfection phase IIa. This pattern is similar to that observed for female Kunmin mice, whose mass gain was retarded when their dietary intake was reduced by $20 \%$ but who reached masses comparable to those of control mice after 3 months (Wu et al. 2002). It should be noted that the response of rodents to energyrestricted diets appears to be dependent on the feeding regimen. Increases in intake of low-quality food have been reported for the prairie vole, Microtus ochrogaster (Wagner, 1842), so long as food availability is not limited (Voltura and Wunder 1998), and long-term reductions of body mass appear to occur only when dietary restriction involves controlled access to food (Curi and Hell 1986; Luz et al. 1995; Ferraris et al. 2001), which induces a meal-like pattern of feeding with high activity in anticipation of "meal time" and prolonged feeding bouts (Goodrick et al. 1983; Duffy et al. $1990 a, 1990 b)$. In our arena study, mice had 24-h access to the respective diets, and any resulting changes should therefore be directly attributable to the energy restriction rather than secondary consequences of the feeding protocol.

Although mass loss in association with $H$. polygyus infection is not usually reported (Minkus et al. 1992; Kristan and Hammond 2000, 2001), Symons and Jones (1974) found reduced mass gain over a 2-week period following infection and Gregory (1991) reported a negative correlation between intensity of naturally acquired $H$. polygyrus infection in outdoor enclosures and masses of wood mice. In the present study, the temporary mass loss of mice from the ES arenas during phase IIa (Fig. 1b) (days 14-28 p.i.) corresponded not only with the highest parasite loads in these mice (Fig. 2b) but also the influx of new, "second-generation" larvae (beginning on about day 17 p.i.) developing from eggs deposited by the infected mice. In contrast, mice in the ER arenas retained their mass.

Our mice demonstrated behavioural adaptations to the concurrent stresses of an ER diet and infection, consistent with previous reports suggesting allocation of energetic resources in response to nutrient availability and urgency of requirements (Sandland and Minchella 2003). The elevated number of feeding bouts (ES arenas) and the elevated total feeding duration (ER arenas) during early postinfection phase IIa are consistent with efforts to increase nutrient acquisition in response to infection, whereas the overall hypoactivity in phase IIa (ER arenas) and phase IIb (ES arenas) and the elevated nesting behaviours in phase IIb (ES arenas) are consistent with attempts to reduce energy expenditure in response to infection. Mice have been reported to allocate a greater proportion of time to sleeping when demands for anabolic functions such as growth, immunity, and tissue repair 




are high (Rollo et al. 1997). Additionally, the decreased grooming in phase IIa (ER arenas) and phase IIb (ES arenas) and the reduced peat contact in phase IIa (ER arenas) would have benefited mice by reducing exposure to parasite larvae. Our study also showed that mice reduced total activity in response to infection in both ER and ES arenas. Although Brown et al. (1994) found that $H$. polygyrus-infected male wood mice moved faster and farther than uninfected mice, our results show that the frequency with which infected mice change behaviours is lower than that in uninfected mice (ER arenas, phase IIa; ES arenas, phase IIb). Similarly, $H$. polygyrus-induced mass loss has also been associated with reduced activity following disturbance, whereas dietinduced mass loss led to marked hyperactivity (Symons and Jones 1974).

In designing this experiment, we had hypothesized that the dynamic pattern of parasite accumulation in mice would be driven by reduced immunocompetence in the ER mice or by reduced frequency of transmission-associated behaviours in the ER arenas. The immunocompetence hypothesis was not supported by our data because mice in the ER arenas developed resistance to incoming larvae. Worm burdens in mice living in the ER arenas were high in phase IIa and declined in phase IIb (Fig. $2 b$ ) despite continuing availability of high numbers of larvae throughout phase IIb, as evident from sentinel mice (Fig. 2a). This pattern of increase then decrease in worm numbers is typical of a trickle infection or continuous exposure to parasite larvae in immunocompetent mice, where parasite numbers gradually increase until the balance between incoming larvae and parasite mortality results in a gradual decline in worm numbers despite continuing transmission (Slater and Keymer 1986; Scott 1991). In addition, the elevated serum $\operatorname{IgE}$ on day 43 p.i. is consistent with the markedly elevated IgE titers seen when the parasite larvae are being actively destroyed (Katona et al. 1991; Urban et al. 1991; Ing et al. 2000) and may be associated with increased uptake of larvae a week earlier, as indicated by data from the sentinel mice from day 36 p.i. The lack of a diet effect on resistance to infection was unexpected, based on our previous finding that a $20 \%$ or $25 \%$ reduction in energy intake prolongs $H$. polygyrus survival and depresses intestinal and peripheral immune effectors in individually housed mice during controlled challenge infection (Shi et al. 1997; Koski et al. 1999). Reduced immune responses and increased susceptibility to bacterial infection in response to energy restriction have also been observed in young mice (Sun et al. 2001). However, generalizations about the beneficial or detrimental effects of energy restriction on immunity appear to be inappropriate, as energy restriction has been reported to boost immune responses following mitogen stimulation (Pahlavani et al. 2002). Also, the response of specific effectors to calorie restriction differs depending on the tissue; Ha and Woodward (1998) found no effect of calorie restriction on serum IgA levels despite reduced intestinal IgA. It is clear from our data on worm numbers that a functional expulsion mechanism had developed at the site of infection in mice from both ER and ES arenas, and that reduced immunocompetence of mice in the ER arenas did not provide a plausible explanation for our data.

We then evaluated our behavioural data to see whether it substantiated our alternative hypothesis of reduced transmis- 
sion in mice from the ER arenas. Natural infection of mice likely occurs through accidental ingestion of larvae during self-grooming and allo-grooming, as mice and their cage mates become infected when larvae are placed on the skin, unless they are fitted with an Elizabethan collar that prevents grooming (Hernandez and Sukhdeo 1995). Our previous research has shown that infection levels are correlated with grooming, sleeping, digging and mouthing peat, and nesting when mice are exposed to larvae on peat (Tanguay and Scott 1992; Heitman et al. 2003). In the present study, mice rarely slept on the peat, in contrast to the previous studies (Tanguay and Scott 1992; Heitman et al. 2003) where mice had no choice but to sleep directly on the peat that covered the entire surface of the cage. Therefore, there was little reason to expect that nesting would be associated one way or another with transmission in our study. There was no evidence of differences in grooming behaviour between mice from the ER and ES arenas, but contact with peat was higher in mice from the ER arenas (Table 4), presumably leading to higher (not lower) rates of transmission in these mice. How could higher rates of contact with larvae be reconciled with the lower numbers of worms in mice from the ER arenas? In response to high transmission rates, worm numbers initially rise very rapidly but then decline more dramatically to very low levels. This contrasts with the slow, gradual increase in infection levels to a moderate, chronic intensity of infection in experimental animals and human populations exposed to low transmission rates (Abdel-Wahab et al. 1980; Crombie and Anderson 1985; Anderson 1986; Scott 1991; Woolhouse et al. 1991). In our experiment, mice from both ER and ES arenas were initially exposed to identical numbers of larvae; therefore, it is not surprising that the initial rapid increase in infection levels was similar in mice from ER and ES arenas. However, we suggest that the higher rates of contact with peat by mice in the ER arenas produced the equivalent of a higher level of endemicity as the experiment progressed, leading to an overall lower infection level in mice from the ER arenas exposed to higher rates of transmission.

\section{Acknowledgements}

Funding for this research was provided by the Fonds québecois de la recherche sur la nature et les technologies (FQRNT ER-75568) and by the Natural Sciences and Engineering Research Council of Canada (NSERC 3585). Research at the Institute of Parasitology is supported by a Regroupement stratégique from FQRNT, a provincial funding agency.

\section{References}

Abdel-Wahab, M.F., Strickland, G.T., El-Sahly, A., Ahmed, L., Zakaria, S., El Kady, N., and Mahmoud, S. 1980. Schistosomiasis mansoni in an Egyptian village in the Nile Delta. Am. J. Trop. Med. Hyg. 29: 868-874.

Anderson, R.M. 1986. The population dynamics and epidemiology of intestinal nematode infections. Trans. R. Soc. Trop. Med. Hyg. 80: 686-696.

Bronson, F.H., Heideman, P.D., and Kerbeshian, M.C. 1991. Liability of fat stores in peripubertal wild house mice. J. Comp. Physiol. B, 161: 15-18.
Brown, E.D., Macdonald, D.W., Tew, T.E., and Todd, I.A. 1994. Apodemus sylvaticus infected with Heligmosomoides polygyrus (Nematoda) in an arable ecosystem: epidemiology and effects of infection on the movements of male mice. J. Zool. (Lond.), 234: 623-640.

Canadian Council of Animal Care. 1984. Guide to the care and use of experimental animals. Vols. 1 and 2. National Library of Canada, Ottawa, Ont.

Colditz, I.G. 2002. Effects of the immune system on metabolism: implications for production and disease resistance in livestock. Livest. Prod. Sci. 75: 257-268.

Corp, N., Gorman, M.L., and Speakman, J.R. 1997. Ranging behaviour and time budgets of male wood mice Apodemus sylvaticus in different habitats and seasons. Oecologia, 109: 242-250.

Crombie, J.A., and Anderson, R.M. 1985. Population dynamics of Schistosoma mansoni in mice repeatedly exposed to infection. Nature (Lond.), 315: 491-493.

Curi, R., and Hell, N.S. 1986. Metabolic changes of twenty weeks food-restriction schedule in rats. Physiol. Behav. 36: 239-243.

Demas, G.E., Chefer, V., Talan, M.I., and Nelson, R.J. 1997. Metabolic costs of mounting an antigen-stimulated immune response in adult and aged C57BL/6J mice. Am. J. Physiol. 273: R1631R1637.

Derting, T.L., and Compton, S. 2003. Immune response, not immune maintenance, is energetically costly in wild white-footed mice (Peromyscus leucopus). Physiol. Biochem. Zool. 76: 744-752.

Duffy, P.H., Feuers, R., and Hart, R.W. 1990a. Effect of chronic restriction on the circadian regulation of physiological and behavioral variables in old male BCF mice. Chronobiol. Int. 4: $291-$ 303.

Duffy, P.H., Feuers, R., Nakamura, K.D., Leakey, J., and Hart, R.W. 1990b. Effect of chronic caloric restriction on the synchronization of various physiological measures in old female Fischer 344 rats. Chronobiol. Int. 7: 113-124.

Ferraris, R.P., Cao, Q.X., and Prabhakaram, S. 2001. Chronic but not acute energy restriction increases intestinal nutrient transport in mice. J. Nutr. 131: 779-786.

Goodrick, C.L., Ingram, D.K., Reynolds, M.A., Freeman, J.R., and Cider, N.L. 1983. Effects of intermittent feeding upon growth, activity, and lifespan in rats allowed voluntary exercise. Exp. Aging Res. 9: 203-209.

Gregory, R.D. 1991. Parasite epidemiology and host population growth: Heligmosomoides polygyrus (Nematoda) in enclosed wood mouse populations. J. Anim. Ecol. 60: 805-821.

Ha, C.-L., and Woodward, B. 1998. Depression in the quantity of intestinal secretory $\operatorname{IgA}$ and in the expression of the polymeric immunoglobulin receptor in caloric deficiency of the weanling mouse. Lab. Investig. 78: 1255-1266.

Heitman, T.L., Koski, K.G., and Scott, M.E. 2003. Energy deficiency alters behaviours involved in transmission of Heligmosomoides polygyrus. Can. J. Zool. 81: 1767-1773.

Hernandez, A.D., and Sukhdeo, M.V.K. 1995. Host grooming and the transmission strategy of Heligmosomoides polygyrus. J. Parasitol. 81: 864-869.

Hunter, E.S., and Sadler, T.W. 1987. D-(-)beta-hydroxybutyrateinduced effects on mouse embryos in vitro. Teratology, 36: 259 264.

Ing, R., Su, Z., Scott, M.E., and Koski, K.G. 2000. Suppressed T helper 2 immunity and prolonged survival of a nematode parasite in protein-malnourished mice. Proc. Natl. Acad. Sci. U.S.A. 97: 7078-7083.

Katona, I.M., Urban, J.F., Jr., Kang, S.S., Paul, W.E., and Finkelman, F.D. 1991. IL-4 requirements for the generation of secondary in vivo IgE responses. J. Immunol. 146: 4215-4221. 
Kerboeuf, D. 1982. Egg output of Heligmosomoides polygyrus (Nematospiroides dubius) in mice given multiple infections of constant or increasing size. Ann. Rech. Vet. 13: 357-368.

Koski, K.G., Su, Z., and Scott, M.E. 1999. Energy deficits suppress both systemic and gut immunity during infection. Biochem. Biophys. Res. Commun. 264: 796-801.

Kowal, M., Buda-Lewandowska, D., Plytycz, B., and Styrna, J. 2002. Day/night food consumption in mice is strain and agedependent. Folia Biol. (Cracow), 50: 1-3.

Kristan, D.M., and Hammond, K.A. 2000. Combined effects of cold exposure and sub-lethal intestinal parasites on host morphology and physiology. J. Exp. Med. 203: 3495-3504.

Kristan, D.M., and Hammond, K.A. 2001. Parasite infection and caloric restriction induce physiological and morphological plasticity. Am. J. Physiol. 281: R502-R510.

Lewis, C.E., Clark, T.W., and Derting, T.L. 2001. Food selection by the white-footed mouse (Peromyscus leucopus) on the basis of energy and protein content. Can. J. Zool. 79: 562-568.

Luz, J., Griggio, M.A., Natrieli, R.M., and Aumond, M.D. 1995. Energy balance of rats subjected to continuous and intermittent food restriction. Braz. J. Med. Biol. Res. 28: 1019-1023.

Mackintosh, J.H. 1981. Behaviour of the house mouse. In Biology of the house mouse. Symposia of the Zoological Society of London, No. 47. Edited by R.J. Berry. Academic Press, New York. pp. 337-365.

McCarter, R.J., and McGee, J.R. 1989. Transient reduction of metabolic rate by food restriction. Am. J. Physiol. 257: E175-E179.

Miller, A.L., Kiney, C.A., Cordry, D.H., and Staton, D.M. 1982. Interactions between glucose and ketone body use by developing brain. Dev. Brain Res. 4: 443-450.

Minkus, T.M., Koski, K.G., and Scott, M.E. 1992. Marginal zinc deficiency has no effect on primary or challenge infection with Heligmosomoides polygyrus (Nematoda). J. Nutr. 122: 570-579.

National Research Council. 1995. Nutrient requirements of the mouse. In Nutrient requirements of laboratory animals. National Academies Press, Washington, D.C. pp. 80-102.

Pahlavani, M.A., Vargas, D.A., Evans, T.R., Shu, J.H., and Nelson, J.F. 2002. Melatonin fails to modulate immune parameters influenced by calorie restriction in aging Fischer 344 rats. Exp. Biol. Med. 227: 201-207.

Perrigo, G., and Bronson, F.H. 1985. Behavioral and physiological responses of female house mice to foraging. Physiol. Behav. 34: 437-440.

Rollo, C.D., Foss, J., Lachmansingh, E., and Singh, R. 1997. Behavioural rhythmicity in tranasgenic growth hormone mice: trade-offs, energetics, and sleep-wake cycles. Can. J. Zool. 75: 1020-1034.

Sandland, G.J., and Minchella, D.J. 2003. Costs of immune defense: an enigma wrapped in an environmental cloak? Trends Parasitol. 19: 571-574.
Santos-Pinto, F.N., Luz, J., and Griggio, M.A. 2001. Energy expenditure of rats subjected to long-term food deprivation. Int. J. Food Sci. Nutr. 52: 193-200.

Scott, M.E. 1988. Predisposition of mice to Heligmosomoides polygyrus and Aspiculuris tetraptera (Nematoda). Parasitology, 97: $101-114$

Scott, M.E. 1990. An experimental and theoretical study of the dynamics of a mouse-nematode (Heligmosomoides polygyrus) interaction. Parasitology, 101: 75-92.

Scott, M.E. 1991. Heligmosomoides polygyrus (Nematoda): susceptible and resistant strains of mice are indistinguishable following natural infection. Parasitology, 103: 429-438.

Sheldon, B.C., and Verhulst, S. 1996. Ecological immunology: costly parasite defenses and trade-offs in evolutionary ecology. Trends Ecol. Evol. 11: 317-321.

Shi, H.N., Koski, K.G., Stevenson, M.M., and Scott, M.E. 1997. Zinc deficiency and energy restriction modify immune responses in mice during both primary and challenge infection with Heligmosomoides polygyrus (Nematoda). Parasite Immunol. (Oxf.), 19: 363-373.

Slater, A.F.G., and Keymer, A.E. 1986. Heligmosomoides polygyrus (Nematoda): the influence of dietary protein on the dynamics of repeated infection. Proc. R. Soc. Lond. B Biol. Sci. 229: 69-93.

Sun, D., Mathukumar, A.R., Lawrence, R.A., and Fernandes, G. 2001. Effects of calorie restriction on polymicrobial peritonitis induced by cecum ligation and puncture in young C57BL/6 mice. Clin. Diagn. Lab. Immunol. 8: 1003-1011.

Symons, L.E.A., and Jones, W.O. 1974. Basal metabolic rate and lipid and liver glycogen in mice infected by the nematode Nematospiroides dubius. Int. J. Parasitol. 4: 301-305.

Tanguay, G.V., and Scott, M.E. 1992. Factors generating aggregation of Heligmosomoides polygyrus (Nematoda) in laboratory mice. Parasitology, 104: 519-529.

Urban, J.F., Jr., Maliszewski, C.R., Madden, K.B., Katona, I.M., and Finkelman, F.D. 1991. IL-4 treatment can cure established gastrointestinal nematode infections in immunocompetent and immunodeficient mice. J. Immunol. 154: 4675-4684.

van Oortmerssen, G.A. 1971. Biological significance, genetics and evolutionary origin of variability in behaviour within and between inbred strains of mice (Mus musculus). Behaviour, 38: 1-98.

Voltura, M.B., and Wunder, B.A. 1998. Effects of ambient temperature, diet quality, and food restriction on body composition dynamics of the prairie vole, Microtus ochrogaster. Physiol. Zool. 71: $321-328$.

Woolhouse, M.E.J., Taylor, P., Matanhire, D., and Chandiwana, S.K. 1991. Acquired immunity and epidemiology of Schistosoma haematobium. Nature (Lond.), 351: 757-759.

Wu, A., Wan, F., Sun, X., and Liu, Y. 2002. Effects of dietary restriction on growth, neurobehavior, and reproduction in developing Kunmin mice. Toxicol. Sci. 70: 238-244. 